\title{
Exploitable Potential, Theoretical Potential, Technical Potential, Storage Potential and Impediments to Development of the Potential: The Nepalese Perspective
}

\section{Dr. Hari Man Shrestha}

\begin{abstract}
Exploitable potential is an ultimate derivable of theoretical potential, technical potential and/or storage potential. A number of hurdles come across when a potential site has to be exploited, thus, all theoretically and/or technically available potential cannot actually be developed/ exploited. Nepal is not an exception in this respect. Exploitation of run-of-river schemes has much less hurdle in comparison with storage development. The storage development, particularly the larger scale development, has even international implications, because the benefits of such development spread far beyond the national boundary. In the Nepalese case the downstream country, particularly India, is reluctant to recognize the downstream flow regulation benefits arising from flood-control and dry season flow augmentation. As such the current focus of exploitation of Nepalese hydro-potential should be on run-of-river type development and smaller size storage developments which can easily be materialized without much hurdle, but in a coordinated and well scheduled manner in a way not to hamper the larger storage development at the opportune future dates.
\end{abstract}

Keywords: Potentials, reservoirs, smoothening capacity, utilization factor, Nepal

\section{Introduction}

$\mathrm{E}$ xploitable potential differs from theoretical and technical potential. The exploitable potential is only that potential which could realistically be developed. For a project to become realistically developable, number of pre-requisites need to be fulfilled, e.g., the project should be technically sound, socially as well as politically acceptable, environmentally friendly and economically as well as financially attractive. These factors combinedly play decisive role in assessing the exploitable potential. In the case of water resources projects, due to quite uneven distribution of flow time and space-wise, if wet season flow could not be stored by building high dams to create storage reservoirs, the utilization factor of available water sharply reduces. Without storage the wet season flow will continue to flow under natural condition creating flood havocs as usual, at the same time the dry season flow cannot be increased for useful purposes as per the need of time and quantity required.

For the Nepalese context, due to unique topography almost all the potential dam/reservoir sites are located at the lower reaches of rivers. Hence the positive effect of flow regulation at the upper reaches is almost zero-limited to natural flow regulation depending on snow regime and melted flows from glaciated zones and glacier lakes. This explains even after fulfilling the above mentioned pre-requisites, the exploitable potential in respect of water use will be quite low. Over and above different development activities undertaken and undergoing along the river valleys without considering the future water resources development are going to impede storage development that will further reduce the exploitable potential. Already some of these potential areas for creation of storage dams/ reservoirs have been constrained/encroached by a number of development activities that have occurred due to uncoordinated planning and implementation.
Following sections present facts and figures on these aspects.

Theoretical Potential versus Storage Potential The estimate of theoretical potential of Nepal goes back to the period of 1963-1966, when as a result of study connected with the preparation of $\mathrm{PhD}$ thesis by the author, the figures of $126,400 \mathrm{MW}$, 83,280 MW and 11,300 MW (Reference-1) were obtained respectively for basin potential, potential concentrated in the river courses and the minimum potential available continuously throughout the year for $90 \%$ of the time. Of these potentials, the first and second categories take into account overall power/ energy of all the waters falling/flowing in the Nepal territory, i.e., the potential is based on average flow availability, while the third one is based on $90 \%$ exceedance of flow or the flow continuously available for $90 \%$ of time of a year. Between the first and second, the difference is that the first category of potential takes also into account the slope energy besides the energy concentrated in the river courses, while the second category potential includes only the potential concentrated on river courses having catchment areas $300 \mathrm{~km}^{2}$ and more. During that study 33 rivers categorized into large having catchment areas 1,000 $\mathrm{km}^{2}$ and more and 82 rivers categorized into smaller having catchments between $300 \mathrm{~km}^{2}$ and $1,000 \mathrm{~km}^{2}$ were included.

The storage potential is dependent on the topographical conditions. Due to steep topography combined with deeper river valleys in the upper river reaches of Nepal, the potential for storage even with high dams are quite low. As the rivers of Nepal are mostly of type having concave profiles, most of the development sites at upper reaches will be high head derivation type without seasonal flow regulation potential. The potential storage sites for flow regulation practically limited to lower and middle reaches of river courses. Even a $269 \mathrm{~m}$ high dam at the lower-most site on the Koshi has only around $66 \%$ flow smoothening capacity, (see Table-1 below). 


\begin{tabular}{|c|c|c|c|c|c|c|c|c|c|c|c|c|c|c|}
\hline \multirow{2}{*}{$\begin{array}{l}\text { Dis- } \\
\text { charge } \\
\left(\mathrm{m}^{3} / \mathrm{s}\right)\end{array}$} & \multicolumn{12}{|c|}{ Months } & \multirow{2}{*}{$\begin{array}{c}\text { Annual } \\
\text { Average } \\
\left(\mathrm{m}^{3} / \mathrm{s}\right) / \\
\text { Smoothened } \\
\text { flow }\end{array}$} & \multirow[b]{2}{*}{$\begin{array}{c}\text { Regulability } \\
(\%)\end{array}$} \\
\hline & Jan & Feb & Mar & Apr & May & June & July & Aug & Sept & Oct & Nov & Dec & & \\
\hline \multicolumn{15}{|c|}{ Mahakali River (at Pancheswor site): Active Storage Volume $=6560 \mathrm{X} 106 \mathrm{~m}^{3}$} \\
\hline $\begin{array}{l}\text { Average } \\
\text { Monthly }\end{array}$ & 165 & 148 & 156 & 203 & 335 & 634 & 1338 & 1798 & 1198 & 534 & 277 & 195 & 582 & \multirow[b]{2}{*}{97.6} \\
\hline $\begin{array}{l}\text { Dry } \\
\text { Season } \\
\text { Augmen- } \\
\text { tation } \\
\end{array}$ & 403 & 420 & 412 & 365 & 233 & & & & & 34 & 291 & 373 & 568 & \\
\hline \multicolumn{15}{|c|}{ Karnali River (at Chisapani site): Active Storage Volume $=16200 \times 106 \mathrm{~m}^{3}$} \\
\hline $\begin{array}{l}\text { Average } \\
\text { Monthly }\end{array}$ & 350 & 311 & 329 & 435 & 738 & 1460 & 3180 & 4260 & 2910 & 1240 & 624 & 429 & 1360 & \multirow[b]{2}{*}{98.2} \\
\hline $\begin{array}{l}\text { Dry } \\
\text { Season } \\
\text { Augme } \\
\text { ntation }\end{array}$ & 986 & 1025 & 1007 & 901 & 598 & & & & & 96 & 712 & 907 & 1336 & \\
\hline \multicolumn{15}{|c|}{ Kaligandaki River (at Kaligandaki-1 site): Active Storage Volume $=5200 \times 10^{6} \mathrm{~m}^{3}$} \\
\hline $\begin{array}{l}\text { Average } \\
\text { Monthly }\end{array}$ & 76.6 & 64.6 & 65.0 & 86.2 & 136.7 & 375.4 & 988.1 & 1128.7 & 885.6 & 331.5 & 162.5 & 104.1 & 359.9 & \multirow[b]{2}{*}{$100 \%$} \\
\hline $\begin{array}{l}\text { Dry } \\
\text { Season } \\
\text { Augmen- } \\
\text { tation }\end{array}$ & 283.3 & 295.3 & 294.9 & 273.7 & 223.2 & & & & & 28.4 & 197.4 & 255.8 & 359.9 & \\
\hline \multicolumn{15}{|c|}{ Trishuliganga River (Site at d/s of Mugling): Active Storage Volume $=6700 \times 106 \mathrm{~m}^{3}$} \\
\hline $\begin{array}{l}\text { Average } \\
\text { Monthly }\end{array}$ & 181 & 157 & 166 & 226 & 403 & 945 & 1872 & 2185 & 1870 & 654 & 357 & 236 & 735 & \multirow[b]{2}{*}{$83.5 \%$} \\
\hline $\begin{array}{l}\text { Dry } \\
\text { Season } \\
\text { Augmen- } \\
\text { tation }\end{array}$ & 432 & 456 & 447 & 387 & 210 & & & & & & 256 & 377 & 613 & \\
\hline \multicolumn{15}{|c|}{ Saptakoshi River (at Barahshetra site): Active Storage Volume $=9370 \times 106 \mathrm{~m}^{3}$} \\
\hline $\begin{array}{l}\text { Average } \\
\text { Monthly }\end{array}$ & 406 & 348 & 353 & 440 & 784 & 1840 & 3890 & 4390 & 3410 & 1630 & 867 & 555 & 1590 & \multirow[b]{2}{*}{65.72} \\
\hline $\begin{array}{l}\text { Dry } \\
\text { Season } \\
\text { Augmen- } \\
\text { tation }\end{array}$ & 639 & 697 & 692 & 605 & 261 & & & & & & 178 & 490 & 1045 & \\
\hline
\end{tabular}

Table1: Flow Smoothening Potential and Dry Season Flow Augmentation Capacities of Some Identified Large Storage Projects

Note: Active Storage Volume, dry season augmentation potential as well as regulability factor or smoothening capacity or water utilization factor change with change of dam height. Similarly, the storage dams in cascade increase the regulability factor.

During the course of preparation of BangladeshNepal Joint Report on Flood Mitigation Measures and Multiple Use of Water Resources (1989), the author with its Nepalese team members made an effort to compile information/data on all the potential high dam storage sites of Nepal and came up with nine large storage sites with more than 5 billion $\mathrm{m}^{3}$ storage (gross) capacity, 11 medium storage sites with capacities lying between one and five billion $\mathrm{m}^{3}$ and eight with less than one billion $\mathrm{m}^{3}$ excluding the two mutually exclusive sites (Reference-2). They together have capacities of 138.5 billion $\mathrm{m}^{3}$ of gross and 82.2 billion $\mathrm{m}^{3}$ of active storage volumes for seasonal flow regulation. There are few number of other sites identified at later dates by different entities, but except the Nalsyaugad storage site others seem to be non-capable for seasonal flow regulation. Information on these sites including those of Nalsyaugad are not readily available. In any circumstances the newly identified sites combined together may constitute only much less than $5 \%$ of active storage volume when compared with the active storage volume of the previously identified sites. The flow smoothening potentials of five large category storage dam sites along with their quantifications, water utilization (regulability) factors and dry season flow augmentation capacities are given in Table-1 for illustration. For these estimates the data presented in "Hydrological Estimates in Nepal, June 2004 of Department of Hydrology and Meteorology (DHM) by Sharma K.P. and Adhikari N.R." and the report on "Pancheswor Multipurpose Project (1995), HMG/N" were utilized. Also the report entitled "Indo-Bangladesh Sharing of lean season flow of the Ganges at Farakka and Possibilities of Augmenting those Flows (April, 1995) prepared for Institute 
of Integrated Development Studies (IIDS) by the author along with B. K. Pradhan and K. Shanker Yogacharya has been referred. The active storage volume available although is in the order of only $36.5 \%$ total annual cross-boundary flows, its value will be great, around US $\$ 4.39$ billion/year worth, if the value adopted between Lesotho and South Africa will be taken as reference. It is US $\$ 53381$ per million $\mathrm{m}^{3}$ in average (Refer Issue\# 14, Hydro Nepal). In addition, due to the capturing capacity of flood waters of these reservoirs, there will be substantial flood control benefits too particularly at downstream reaches.

However, it must be emphasized here that the creation of such storage reservoirs by constructing high dams is not possible without cost and without overcoming the varieties of hurdles associated with submergence. In addition to construction cost, the associated costs connected with submergence such as sacrifice of fertile land, forest and other natural resources, resettlement of people, relocation of built-up properties (individual, public and social) including different infrastructural facilities, psychological, socio-economical and environmental disturbances to be incurred. In the case of 1200 MW Budhigandaki storage dam project (dam height $=263 \mathrm{~m}$ and active storage volume of reservoir $=2226 \mathrm{X} 106 \mathrm{~m}^{3}$ ), where so far the infrastructural facilities are still relatively less developed, the compensatory cost alone constitutes $21 \%$ of total project cost of US\$2,550 million (Reference-3). Thus, increasing the potential of a site by means of creation of storage reservoir (s) through construction of high dam entails large costs and could be justified only when all the multiple benefits accruable in the downstream reaches are also fully accounted for. As such, if the cooperations from the downstream country (ies) that receive major share of floodcontrol and irrigation benefits accruable respectively due to storage of flood water and augmentation of dry season flow, particularly from the large storage projects, are not forth-coming, these sites will have to be used as run-of river type development sites. Under this situation even the theoretical potential will shrink down to 53,836 MW installable at $40 \%$ exceedance of flow and 80\% efficiency as estimated by Dr. Raghunath Jha, Shah Rupesh and Adhikari Sudip. P (Refer Issue\# 7, Hydro Nepal). It could have been some more, if instead of considering only 23 number of rivers during that study similar number of rivers as in 1963-1966 study by the author would have been considered.

\section{Technical Potential}

The technical potential differs from the theoretical in the sense that it is based on technical schemes worked out at the desk study level using larger scale topographical maps and verified at the field for their technical viability at least at the reconnaissance level. Thus, the assessment of this potential depends on territorial coverage of such studies. The possible range of upper limit of technical potential of Nepal for the first time was indicated in 1968 as 50 to $70 \%$ of theoretical potential concentrated in the river courses based on the schemes worked out in lower Karnali, Kankai, lower Tamor, lower Gandaki and Kulekhani-Rapti (Reference-4). In order to present more complete and realistic picture of technical potential, the author in 1995 in connection with the preparation of Supporting Documents for Perspective Energy Plan of Nepal made an effort to compile from different sources all the identified projects and produced a report entitled "Energy Perspective Plan: Technical Reference-Hydropower Sector" listing the technical schemes with capacities and their basic parameters along with locating the project sites in a map. As per this report such projects numbered 122, of which 23 projects were covered at that time at least to prefeasibility level study. The technical potential of all these 122 projects added together gives $43,442 \mathrm{MW}$ in terms of installed capacity at different capacity factors and more than $179,000 \mathrm{GWh} /$ annum in terms of energy generation potential. As of now, such a full, updated compilation is not available, although a great number of smaller projects have been identified under the umbrella of Department of Electricity Development (DoED) and through licensing to the other developers after promulgation of policy to open private participation in hydropower development. It is to be stated here that these, in many cases, must have been overlapped or have already been mutually exclusive with those included in the earlier basin master plan and other individual project studies.

\section{Exploitable Potential}

The exploitable or realistically developable potential, unlike theoretical and technical potentials, changes with time and circumstances as it is dependent on numerous factors given in the introductory section above, but will never exceed technical or theoretical potential particularly in terms of energy generation potential. Specially the economic and financial viabilities are dependent on availability of competing alternative sources, while exploitable potential is dependent not only on economic and financial factors but also on socio-economic, political and environmental factors. The increase in the population density/settlements along the river valley that could occur due to extensive/intensive infrastructural development such as transportation networks, urbanization, industrialization, market centres, tourism/resorts, etc including the run-of - river type hydropower projects themselves may impede storage development reducing sharply the water utilization factor. Again the marketability of the seasonal/ secondary/wet season energy is another factor. For Nepalese system, the produceable wet season energy may not all be consumable, while for Indian system due to availability of different indigenous sources for electricity generation, the maximization of use of even the wet season hydro-energy in run-of - river type projects becomes viable for preserving the costly and unrenewable energy resources for future use. This has been evidenced during conduct of PDA (Project Development Agreement) with Indian entities, whereby the installed capacities of each 
Upper Karnali and Arun-3 hydroelectric projects has been increased to $900 \mathrm{MW}$ instead of $360 \mathrm{MW}$ and 402/201 MW respectively designed previously for the Nepalese power market.

There have been some estimates of exploitable potential, although these figures do not remain constant and bound to change with time. In May 1987, a consulting company, Lahmeyer International, $\mathrm{GmbH}$, of the Federal Republic of Germany produced a report entitled "Trans-country Power Exchange and Development" for ESCAP (Economic and Social Commission for Asia and the Pacific), in which total exploitable hydropower potential of Nepal has been indicated as 68,700 GWh/annum. Similarly, Mr Rabindra Bahadur Shrestha, the former Deputy Managing Director of Nepal Electricity Authority (NEA) in his article entitled "Power Sector and Hydropower Development in Nepal" (Refer Issue\#16 of Hydro Nepal) says that the collective potential of Nepal's cost-effective current R-o-R (Run-of-River) at 1500 US $\$$ per KW is approximately $12,000 \mathrm{MW}$. Among these estimates, the Lahmeyer's estimate is confusing, because in its same report a list of 21 trans-country energy export projects has been given, the total energy potential of these projects alone is $102,720 \mathrm{GWh} /$ annum (greater than the country total of 68,700 GWh/annum, Reference-5)

\section{Evidences of Impediments to Storage Development that have been already Appeared} Not to speak of coordinated planning and development with sectors other than power, even the project development within the hydropower sector has not been coordinated and well visualized for future development. The policy of providing licenses to the private sector has been implemented in first-come-first-serve basis without considering that these smaller developments could preclude important medium and larger scale developments at an appropriate time. Number of such examples do already exist-the construction license issued for Kabeli-A (37.6 MW) hydroelectric project is going to affect Tamor-1 Storage Project (762 MW) making this project unfeasible due to requiring of lowering down of its full supply level (Reference-6). In fact, Kabeli-A (30 MW) was to be constructed towards the end of ninties (before $2000 \mathrm{AD}$ ) and would have completed its economic life by the time Tamor-1 Storage becomes fit for Nepal's power market, but due to delay in its implementation the present situation has emerged. Similarly, the possibility of development of Trishuliganga storage dam project (1500 MW) is already at stake, because along the Trshuliganga river valley there have already been taken place a number of development activities including the Naubise-Mugling road corridor representing the prime national highway connecting Kathmandu with India, not to speak of Marsyangdi (69 MW) and Middle Marsyangdi (70 MW) hydroelectric projects. Again, the Kaligandaki-A (144 MW) hydroelectric project is located within the submergence area of Kaligandaki-1 Storage Project (1600 MW). These $\mathrm{R}-\mathrm{o}-\mathrm{R}$ hydroelectric projects, however, may serve their economic lives, but relocation of NaubiseMugling road corridor could be difficult. Similarly, the newly completed Dhulikhel-Bardibas highway connecting Kathmandu with the eastern region is going to create hurdles for storage developments on Sunkoshi river course. Coordinated planning and development with other sectors such as development of transportation network, urbanization, industrialization, establishment of touristic facilities, etc along river valleys are, thus, essential, if the potential multipurpose or hydroelectric storage sites are to be preserved for the future development.

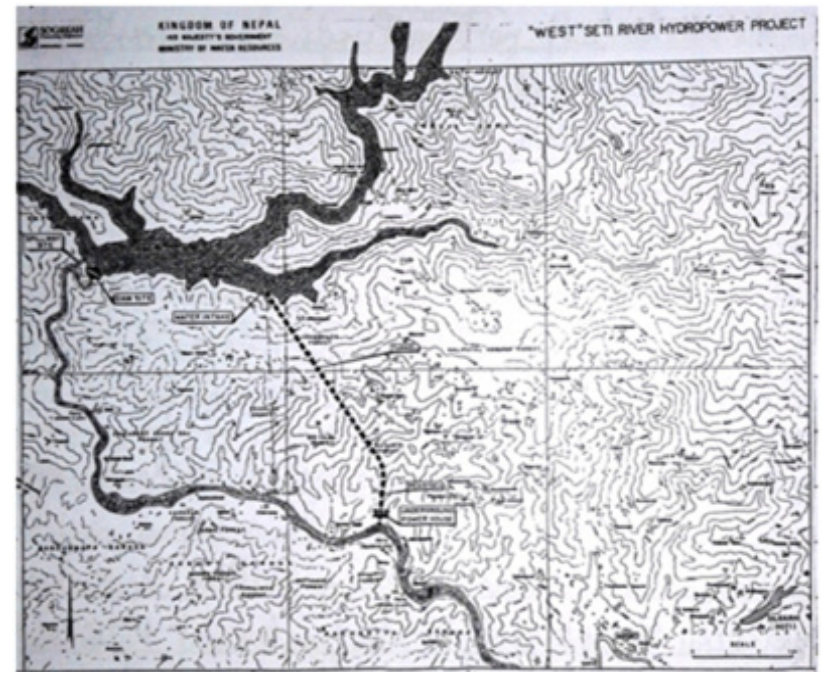

Source: West Seti Hydropower Project-Detailed Feasibility Study Report, February 1991

Figure1: Layout Plan

One other major impediment, particularly for development of larger storage projects, is due to nonrecognition of downstream benefits, particularly by India. Both the flood-control and dry season flow augmentation benefits from these projects flow largely to India. Attraction to storage projects are also due to these added downstream benefits, besides due to increase in water utilization factor in hydropower production. These added benefits are derivable in lieu of allowing the submergence of the fertile land, associated resources and relocation of establishments existing there and resettling the people living there in the concerned river valley. With the attitude of not willingness in putting costs in lieu of such automatically accruable downstream benefits from the part of India, in particular, these projects can never be materialized, because without taking these benefits into account such larger storage projects will hardly become attractive. Even if the project(s) becomes attractive, Nepal has to be compensated justifiably for the losses to be incurred due to submergence in the Nepal territory.

\section{Even a Smallest Effort can help Reduce Some of the Impediments}

At least, if the concerned agency (either Water and Energy Commission Secretariat or Department of Electricity Development) delineates the full supply levels of already identified potential storage 
reservoirs, such as shown in Figure-1 for Seti (West) Storage hydroelectric project by Sogreah of France, in the largest available toposheets of the country showing land uses and disseminate them in a digitized form, these information will serve important basis not only to DoED itself for the purpose of providing new licenses for hydropower projects, but also to various departments/agencies, private companies or individuals working in other sectors of economy or society to avoid to locate their planned facilities within the would-be submergence areas of those potential reservoir sites. Even this type of smallest work can help reduce compensation costs that will be associated with the development of storage projects.

\section{Concluding Remarks}

The actual facts and figures about hydropower potential of Nepal and constraints for development have briefly been outlined in this paper. Making large noises on the potential or by politicizing in a falsified way that Nepal is second richest country in the world after Brazil or quoting an exaggerated figure of 200,000 MW potential as the estimates of Hydro Solutions without any reliable basis (Reference: Article by Er. Gyanendra Lal Pradhan in Issue\#7 of Hydro Nepal) has no sense, when the nation's requirements have not yet been able to fulfill. It is just creation of confusion only. The estimate of theoretical potential with compilation of cadastrial charts, tables, maps, profiles, potentials per unit of river stretch, etc for individual river courses had played in its time important role for picking up river/river stretches and project sites with comparatively higher concentration of potential for priority field surveys and investigations leading to development of basin master plans and individual schemes. No doubt Nepal, as compared to its area, is better favoured in terms of hydropower/water resources endowment per square kilometer of area, but its actual value will depend on how exploitation of this potential will take place.

Keeping in view the analysis given in this paper, it is worth taking into account that Nepal's priority attention should at first be on run-of-river development and, secondly, on smaller storage projects like Kankai (Mainachuli site), Kamala, Bagmati, Uttar Ganga, Sharada-Babai, Bhaluwang (West Rapti), Nalsyaugad, Langtang, Seti (West) and Tamor-1 projects, the benefits of which could largely be enjoyed by Nepal without adversely affecting the downstream users but benefitting them from floodcontrol. Any feasible wet season surplus generation from R-o-R type hydropower projects needs to be low-priced in order that during this period the use of this energy become more competitive/attractive than the use of LPG to reduce its consumption at least in the wet season. Regarding the larger storage projects like Saptakoshi, Budhigandaki, Kaligandaki 1 and 2, Trishuliganga, Karnali at Chisapani, Bheri projects, Pancheswor (Bi-national), etc, they are not the priority projects for Nepal for a foreseeable future. They may be considered for long term future, if downstream countries, particularly India, will come with concrete proposal with cost contribution for creation of large reservoirs in lieu of the downstream flow regulation benefits that they are going to receive from these projects. Even with this, Nepal has to judge their implementability from the points of view of political, socio-economical and environmental acceptability.

In any circumstances, coordinated planning and implementation of activities related to varieties of development sectors including the R-o-R type of hydroelectric development along the river valleys are the must to avoid or minimize the added hurdles for storage development at appropriate dates. As a minimum to start with, the concerned authority (WECS or DoED) needs to be engaged immediately in delineation of reservoir areas of potential reservoir sites in the topographical maps, digitize them and disseminate the information to the concerned as mentioned in above section so that the planned facilities of the concerned developers/agencies or individuals including the new issuance of licenses for hydroelectric projects could, to the extent possible, be located outside the would-be submergence area of the potential storage projects.

Dr. Hari Man Shrestha holds M.Sc. (Hydropower Engineering, September 1957-July 1963) and PhD (Technical Science, September 1963-March 1966) from Moscow Power Institute, the then USSR. He is the first Nepali Ph. D. in Technical Science (Engineering). Dr. Shrestha, while conducting an academic research for his Cadastre of Hydropower Resources PhD thesis at the Moscow Power Institute (then USSR), in 1966 $A D$, came up with an exciting finding, which showed Nepal's theoretical hydropower potential at an 83,0oo MW. He has a wealth of experience spanning over 40 years in the fields of Hydropower and water resources, having worked in different capacities including the Executive Secretary (Chief) of Water and Energy Commission Secretary (WECS) and also an advisor to water and Energy Commission (WEC) during his tenure of services in the Government.

\section{Corresponding E-mail: ssudhii@gmail.com}

\section{References}

Cadastre of Potential Water Power Resources of less studied High Mountainous Regions (with special reference to Nepal) by H.M.Shrestha, 1966

Bangladesh-Nepal Joint Report on Flood Mitigation Measures and Multiple Use of Water Resources (1989) by Bangladesh and Nepalese teams led respectively by MD. Amjad Hossain Khan (Late) and Dr. H.M.Shrestha

Draft Final Feasibility Report on Budhigandaki Hydropower Project by Tractbel Engineering and Jade Consult, November 2014

Water Power Potentiality of Nepal (its theoretical and technical limits), Seventh World Power Conference, 1968 by Hari Man Shrestha

Trans-country Power Exchange and Development for ESCAP (May 1987) by Lahmeyer International

NEA - A year in Review (Fiscal Year 2013/014) 